\title{
PERFORMANCE EVALUATION OF COMMUNITY MICROFINANCE INSTITUTIONS IN JEMBER DISTRICT
}

\author{
Bayu Wijayantini, Maheni Ika Sari, Alfi Arif \\ Muhammadiyah Jember University \\ Jember University, Student of Diponegoro University
}

\begin{abstract}
Community Micro Finance Institution (CMFI) plays a significant role in alleviating poverty, which is the biggest problem in developing countries. This study aims to examine the phenomenon of CMFI development in Jember. This study is conducted using a descriptive statistical analysis and through literature study from literatures relevant to the research theme. The results of the study show that financial performance proxied by ROA has a different trend from total assets and government subsidies. ROA tends to decline even though there are some CMFIs that show good performance. This is contrary to the development of CMFI's total assets which tend to increase throughout Jember, while government subsidies are still accepted in the same amount as intended from year to year.
\end{abstract}

Keywords: CMFI, ROA, subsidies, total assets, poverty

\section{A. Introduction}

The development of the financial sector to the economy is widely influential, however, the financial sector segmentation, which has led to the formal and informal financial sectors, is becoming problematic. It happens because of the limited access to formal sector finance given to the poor, especially marginalized women groups. Difficulties of access, usually based on socioeconomic reasons such as high transaction costs, high risk of credit, and lack of collateral, are believed to be the main reasons. There are various social and economic reasons that underlie the difficulty of the formal sector accessing the informal sector. These include high credit risk and the unavailability of collateral, which is sufficient to cover the credit. In addition, social and cultural barriers, such as low levels of education (the inability to financially record their economic activities),

\footnotetext{
*Corresponding Author.

e-mail: bayu@unmuhjember.ac.id
} 
make the formal sector increasingly reluctant to penetrate the informal sector. Data shows that the largest part of the economy in Indonesia is poor women, which need a solution to be economically empowered. This has inspired the emergence of microfinance institutions that seek to bridge the gap between the poor and micro-entrepreneurs and the financial sector.

Various empirical studies have been conducted to study the development of Community Micro Finance Institutions (CMFI) and its role in alleviating poverty as the biggest problem in developing countries such as Indonesia. For example, Uchida et al. (2007) stated that procession with the conditions of financial liberalization, capital market development, and the company's scale in Japan resulted in many large companies to run and look for sources of funding to capital markets and not to the banking sector anymore. It has caused many large banks to begin to shift their financing to the micro sector financing, where they initially provided loans to large companies. However, the primary role of financing the small and micro sector is still held by small banks, as it cannot be replaced by large banks. This is possible because of the close relationship between the bank and the debtor or relationship lending, as a basis for giving loans. The role of small banks to finance the micro and small sectors in the future is still prospective in Japan. On the other hand, Parianom (2013) noted that in 2004, the number of CMFIs had grown from 54,444 to 373,307 in just one year.

The same phenomenon occurs in Jember, as limited access of poor women and empowerment programs that are still partial and disconnected have not provided significant changes to a better change in life (Supeni \& Sari, 2013). Related to this, Mirfano, Head of the Jember Cooperative and UMKM Service, captured this phenomenon with the inspiration of the Grameen Bank in India. $\mathrm{He}$ argued that poor women have the potential to be economically empowered only if they are given an appropriate empowerment program that addresses their basic problems of very limited financial access. Furthermore, he said that what needs to be done is strengthening financial institutions by initiating the establishment of community microfinance institutions (CMFI) in 2005, and this is supported by the Jember district government through a budget of 2 billion per year starting with 13 CMFI spread in three Inner City Sub-Districts (Kaliwates, 
Sumbersari and Patrang) and six other Sub-Districts, namely, Arjasa, Puger, Panti, Rambipuji, Sumber Jambe, and Tempurejo.

Strengthening the poor's financial institutions certainly needs to be continually improved by the organization and its management, so that it develops well and attracts the community to actively participate in it so that the empowerment of poor women can run sustainably and thus be able to contribute to the reduction of poverty in Jember district. It is this process that underlies Office optimistic cooperative and SMEs in continuing to develop CMFIs as agents of development as well as an institution active in micro enterprise financing for poor women. Based on this, the purpose of this study was to examine the development phenomena of the CMFI performance in Jember, regarding the value of return on assets (ROA), total assets, and government subsidies, over 5 years.

\section{B. Literature Review}

Micro-credit is one of the effective efforts to overcome poverty (Robinson, 2002). Robinson stated that there are classifications of the poor. First is the very poor (the extremely poor), who does not earn income and does not have productive activities. Second is the economically active working poor. Third is low income people, who have income, though not much. The Function of Microfinance Institutions (MFIs) is as a loan service provider institution for productive activities carried out by micro businesses, or for family consumption activities of the poor. In addition, the CMFI also functions as a savings institution, which saves funds which are used as a prerequisite for credit, although in the end often the amount of credit given is greater than the funds collected.

Financial institutions serve as an intermediary in economic activities. Financial institutions will generate added value if the intermediation function is going well. Differentiation of economic activity is not differentiated based on the size of the business carried out, but based on the added value generated by the business scale. Which means that every business that utilizes financial institutions and provides added value will increase people's income. One productive way 
that can be done by the poor, to increase added value is to utilize the intermediary suits of financial institutions.

Efforts to alleviate poverty can be carried out by a wide range of facilities and programs that are either direct or indirect. This activity can be in the form of transfer payments from the government such as food programs, health, education, family planning, settlements, as well as productive business aids such as through loans in the form of micro-credit. So, it can be said that the empowerment of micro-credit will help alleviate poverty, because the existence of micro-credit will make it easier for beginner entrepreneurs. With the growth and development of novice entrepreneurs, becoming micro entrepreneurs, it will increase the number of jobs, and this is very helpful in eradicating poverty (Wijaya, 2005).

Previous studies have shown that microfinance institutions have been able to reduce poverty among their members. Oguejiofor and Unachukwu (2014) showed that the microfinance institution in the Philippines have assisted their members to run business and make investment activities. Addae-Korankye (2012) documented that micro-finance has helped people as the Self-Help Groups to be more productive in obtaining economic activities. Samir et al. (2015) showed that micro-finance institution Amanah Ikhtiar Malaysia has a positive effect on household income of women borrowers. Usman (2015) reported that the microfinance institution has a positive impact on poverty alleviation and the improvement of income level, education, and in building up the living standard of the poors.

Some studies that used the Indonesian context had also found support for the usefulness of microfinance institutions. For example, Asmawati (2015) studied the impact of Islamic microfinance on increasing the income and poverty alleviation on microenterprises in the Province of Aceh and reported that the institution can improve the poors' income. Sabiti and Effendi (2017) reported that the funding-based Islamic microfinance institutions have a positive effect on micro businesses and poverty reduction in the rural areas in the district of Bogor. Deloach and Lamnna (2011) also found that the presence of microfinance institutions within communities has significantly improved the health of children. Thus, microfinance does not only relate to poverty but also helps improving children's health. 
The existing empirical studies have confirmed that the presence of microfinance institution has helped people to reduce their poverty. Given the differences regarding the area and local characteristics, examination of the effectiveness of microfinance institution is still in great demand. The current study is performed to fill in this gap by studying the microfinance phenomenon in the district of Jember, East Java province of Indonesia.

\section{Research Methods}

To achieve the research objectives, the population of the study is all CMFIs in Jember that have complete financial reports from years 2010 to 2014. A total of 149 CMFIs are listed in this research. Observations are made for five consecutive years so that the number of observations in this study is 745 . A descriptive statistical analysis is used in this study and is also displayed in a graphical model to visualize the results of research in supporting the discussion. Enrichment of data analysis is also carried out with literature studies from previous research studies and relevant references to support the results of data analysis.

\section{Results and Discussion}

Evaluation of the development of CMFI in this study is seen from government subsidies, total assets, and profitability proxied by ROA. ROA is a ratio that measures the ability to obtain business benefits and CMFI efficiency in total asset utilization. In this case, the researcher tried to process and present the results of data analysis in a graphical form to facilitate understanding the development of financial performance. Processing and presentation of data is made per district to present more detail of the development on each CMFI in each sub-district in Jember. The number of CMFI per Sub-District is described in Table 1.

As shown in Table 1, there are 149 CMFIs in the district of Jember, spread out over 31 Sub-Districts. The largest CMFI is in the districts of Patrang, Kaliwates, and Sumbersari, which are said to be the City-based Sub-Districts. 
Review of Management and Entrepreneurship

Volume 02, Number 01, April 2018

Table 1 CMFI Data per Sub-District

\begin{tabular}{|c|l|c|c|l|c|}
\hline No. & Sub-District & $\begin{array}{c}\text { Total } \\
\text { CMFI }\end{array}$ & No. & Sub-District & $\begin{array}{c}\text { Total } \\
\text { CMFI }\end{array}$ \\
\hline 1 & Ajung & 3 & 17 & Panti & 2 \\
\hline 2 & Ambulu & 3 & 18 & Patrang & 23 \\
\hline 3 & Arjasa & 2 & 19 & Puger & 3 \\
\hline 4 & Balung & 2 & 20 & Rambipuji & 3 \\
\hline 5 & Bangsalsari & 2 & 21 & Semboro & 3 \\
\hline 6 & Gumukmas & 3 & 22 & Silo & 3 \\
\hline 7 & Jelbuk & 8 & 23 & Sukorambi & 6 \\
\hline 8 & Jenggawah & 2 & 24 & Sukowono & 3 \\
\hline 9 & Jombang & 2 & 25 & Sumber Baru & 2 \\
\hline 10 & Kalisat & 3 & 26 & Sumber jambe & 3 \\
\hline 11 & Kaliwates & 22 & 27 & Sumbersari & 18 \\
\hline 12 & Kencong & 4 & 28 & Tanggul & 3 \\
\hline 13 & Ledokombo & 3 & 29 & Tempurejo & 3 \\
\hline 14 & Mayang & 3 & 30 & Umbulsari & 3 \\
\hline 15 & Mumbulsari & 3 & 31 & Wuluhan & 3 \\
\hline 16 & Pakusari & 3 & & Total & 149 \\
\hline & & & & \\
\hline
\end{tabular}

Source: Dinas Koperasi Jember (2017)

The development of CMFI Jember District's performance, based on government subsidies, total assets and profits, can be seen in Figure 1.

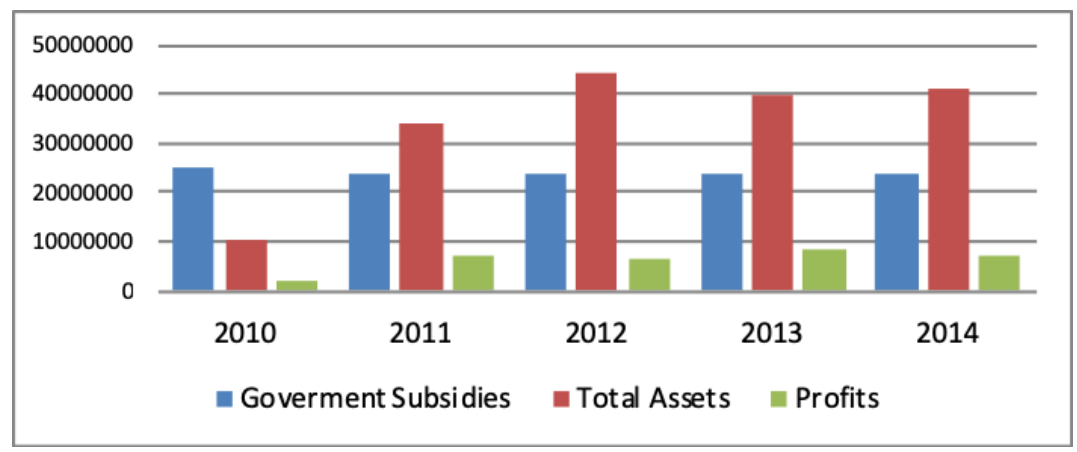

Figure 1 Development of Financial Performance CMFI Jember District 
As can be seen in Figure 1, the level of subsidy provided by the government over several periods tends to be stable on an average of above 20 million per year for each CMFI. The subsidies are fully utilized by the CMFIs, as is evident from the increasing number of assets owned by CMFI during the study period, although there was a slight decrease in 2012. This is consistent with the level of gain or profit of the CMFIs, which tend to increase during the period of research.

\section{Profitability of CMFI}

Looking at the development of the Profitability, it was found that CMFIs in Jember generally have experienced a decline. The decline can be seen in Figure 2.

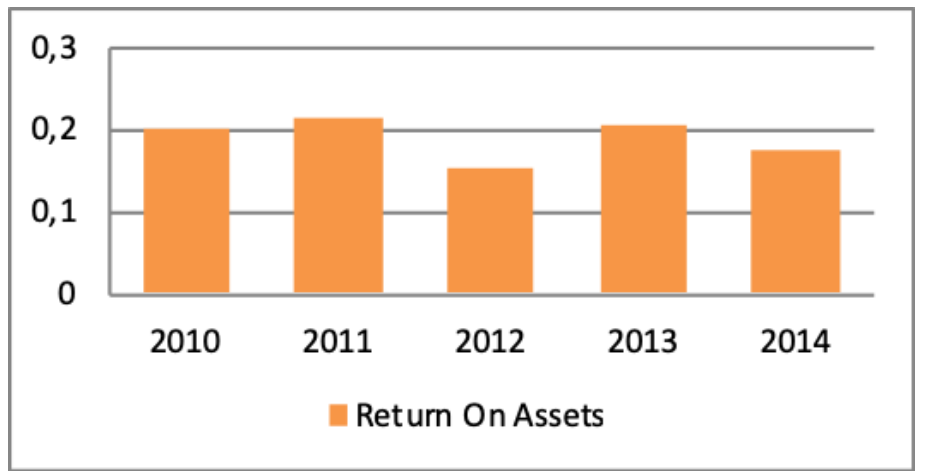

Figure 2 Development of Profitability CMFI in Jember District

Figure 2 shows the Retained Earnings general trend in an approximate level of profitability expected in Return on Assets (ROA). The ROA has declined after rising up in 2013, although not as drastic as in 2012. However, there are increased figures in the middle of the research period. The increases have been experienced by CMFI Krajan, CMFI Bulak Renteng, and CMFI Klompangan in the Ajung sub-district. The data can be seen in Figure 3.

The same trend is evidenced by CMFI Sukorejo and CMFI Siraan in the Bangsalsari Sub-District. However, there are some CMFIs that show increasing ROA from year to year. CMFI Krajan in the sub-district of Balung has the 


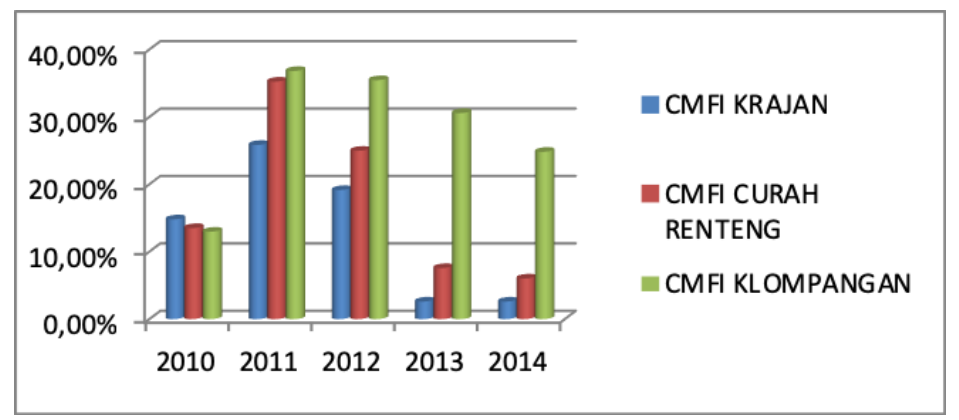

Figure 3 ROA Movement in Ajung Sub-District

exception, as shown in Figure 4. The other CMFIs with positive trend are in the Sub-Districts of Arjasa, Ambulu, Mumbulsari, and Kaliwates.

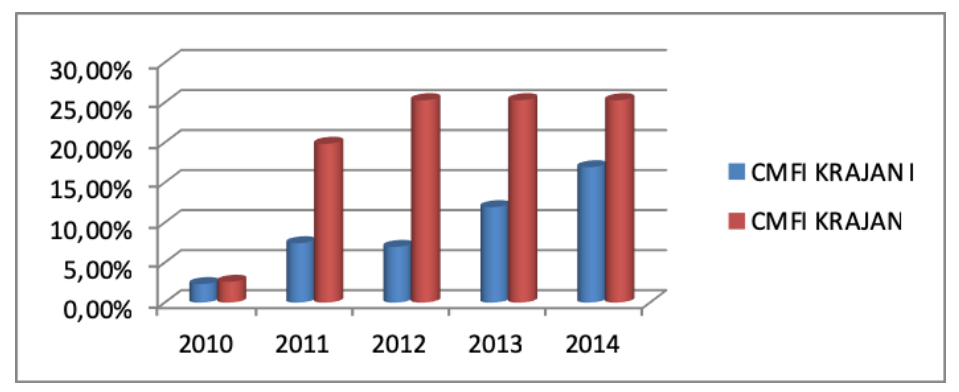

Figure 4 Movement of ROA in Balung Sub-District

On the other hand, the remaining CMFIs have experienced good development in the year 2010, although the figures dropped dramatically in recent years. Among others are the CMFIs in sub-districts Silo and Wuluhan, as shown in Figures 5 and 6.

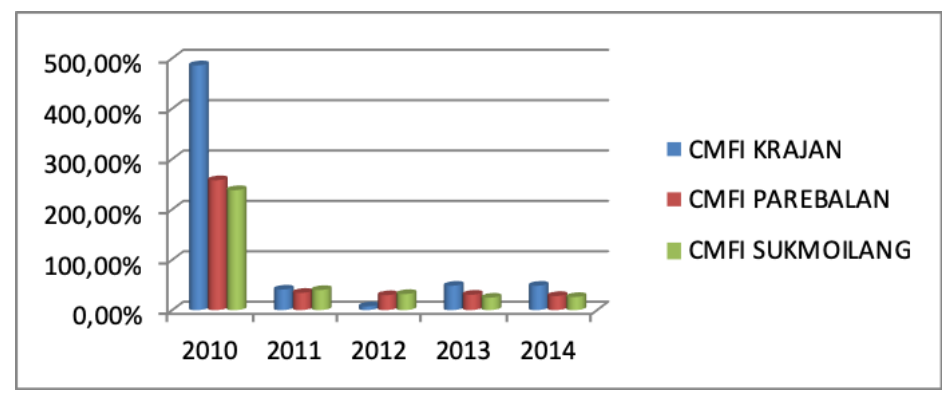

Figure 5 ROA movement in Silo Sub-District 


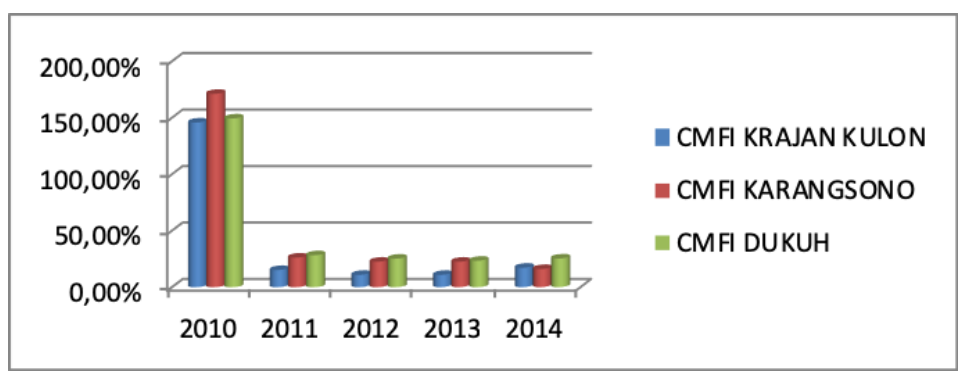

Figure 6 ROA movement in Wuluhan Sub-District

From the results above, it can be seen that the CMFIs' ability to obtain business benefits and CMFI efficiency in the utilization of total assets is still not balanced among CMFIs. This indicates that there is a need for more intense guidance for CMFIs that still has low ROA performance so that they can increase the efficiency of their total asset utilization to gain profit, which in turn will encourage the development of CMFI and the welfare of its members and general economic prosperity in Jember district. The results of this study still show the same trend with the reported development of CMFI in Jember district (Dinas Koperasi and UMKM, 2013). However, this phenomenon shows that the CMFI still has good prospects to develop in the future as the results of the research by Uchida et al. (2008) in Japan, Oguejiofor and Unachukwu (2014) in the Phillipines, Addae-Korankye (2012) in Ghana, Samir et al. (2015) and Usman (2015) in Malaysia or some other Indonesian studies (Asmawati, 2015; Sabiti and Effendi, 2017; Deloach and Lamnna (2011).

\section{CMFI Subsidies}

At the beginning of the innovation in FY 2005, PUM-RTM activities were financed by the Jember APBD in the sum of IDR. 100 million. The budget is used to finance the establishment of 2 units of Gakin Bank in 2 environmental areas, the strengthening of 12 Pokmas groups (60 people), and the provision of venture capital in the form of grants amounting to IDR 50 million which are managed through joint savings and a loan pattern. There is a difference in Bank Gakin's capital financing pattern between 2005-2006 and 2007-2008. In 20052006, the Gakin Bank received grant assistance, while in 2007-2008 Gakin Bank 
received assistance in the form of soft loans, which must be returned within 2 years. According to procured information, this difference is caused by the APBD management rules from the central government.

The total investment of the Regional Government in the PUM-RTM activities including the development of Gakin Bank for 4 budget years reached IDR3,382,141,700,-; the allocation includes institutional reinforcement in the amount of IDR1,510,826,350,-; reinforcement of business capital amounting to IDR1,360,800,000, - which until now has circulated in the form of soft loans for micro entrepreneurs, members of Gakin Bank, and increased skills in the amount of IDR 510,515,350. When compared with the number of poor families receiving 4,423 services (May 2008 data), it can be concluded that to alleviate poverty using the PUM-RTM design, the development pattern of Bank Gakin requires funding of IDR 764,672.- per-person. The value of the ratio will continue to decline in the coming years in line with the increasing number of Gakin Bank members that will occur systematically.

Meanwhile, the role of government subsidies for CMFIs in Jember shows a pattern that is generally similar since 2010 to 2014, as can be seen in Figure 7.

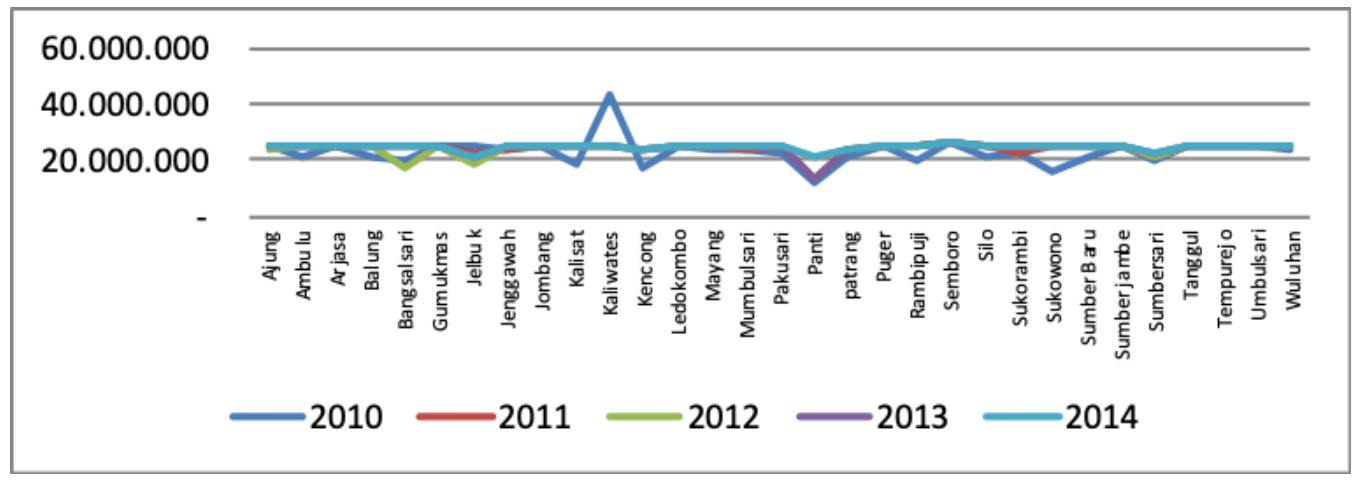

Figure 7 Development of Government Subsidies for CMFI

As shown in Figure 7, it appears that government subsidies for CMFI generally have the same trend year by year for each sub-district, and only Kaliwates Subdistrict in 2010 received subsidies provided that were slightly larger than others, because in 2010 there was quite a large surge in the number CMFIs. These results indicate that until now the CMFIs are still receiving funds 
from the government for daily operations. Supposedly, after nearly a decade of its founding, CMFIs should already be independent financially, but because their ability to obtain the benefits are still not optimal financially, CMFIs still can not be stable enough without government subsidies.

\section{Total Assets CMFI}

Development data CMFI's total assets in this study period show almost the same trend as a whole, which tends to increase (Figure 8).

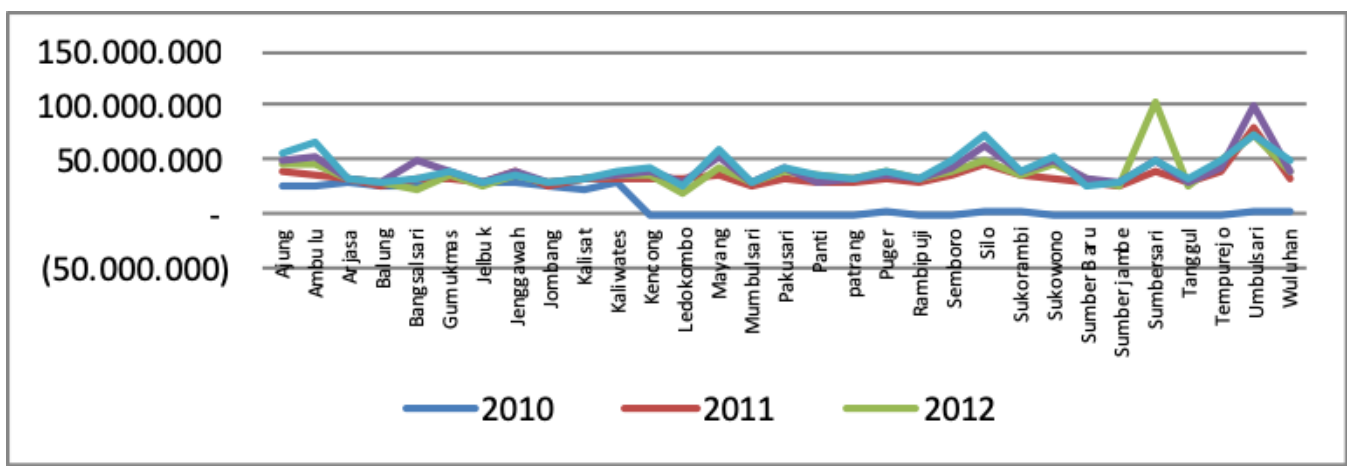

Figure 8 Development of Total Assets CMFI in Each Sub-District

In Figure 8, it can be seen that globally, CMFI total assets have increased from year to year, even though some of them stagnated, such as in the subdistrict of Kalisat, and a fraction longer experienced decline at some point, such as what happened in the sub-districts of Umbulsari and Sumbersari. Its development can be seen Figure 9.

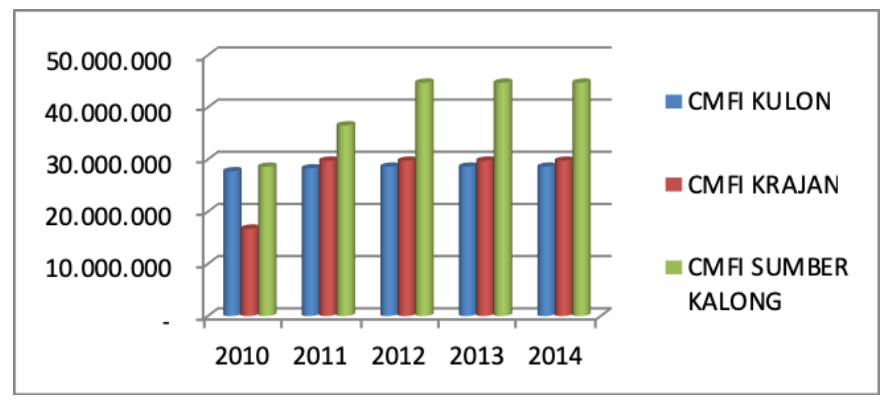

Figure 9 Total Asset Movement in Kalisat Sub-District 
In Figure 9, it can be seen that of the three CMFIs found in Kalisat SubDistrict, the development of Total Assets have stagnated since 2012, although it had risen in the previous years. The development of the total assets in the Umbulsari sub-district CMFI is shown in Figure 10.

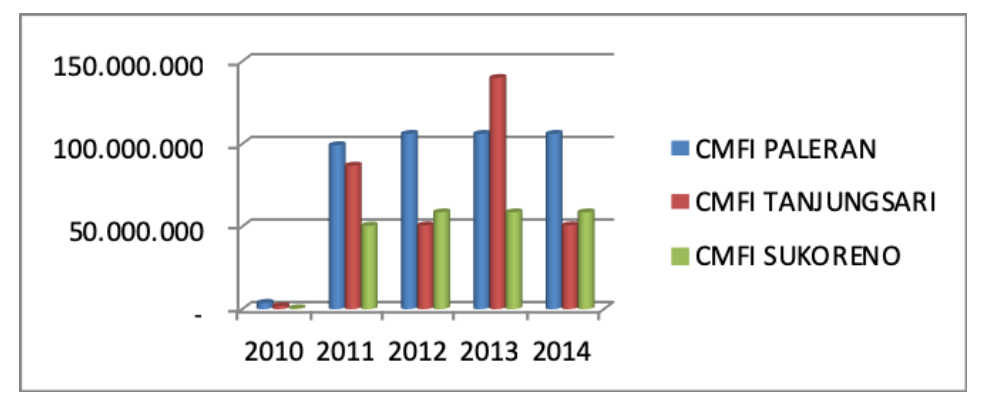

Figure 10 Total Asset Movement in Umbulsari Sub-District

Figure 10 shows that for Sub-District of Umbulsari, three CMFIs experienced stagnant growth in assets, and even CMFI Tanjungsari fell dramatically in 2014. This condition differs from the trend of the development in the entire Jember district, where during the period of 2006 to 2010 a significant increase occurred (Figure 11).

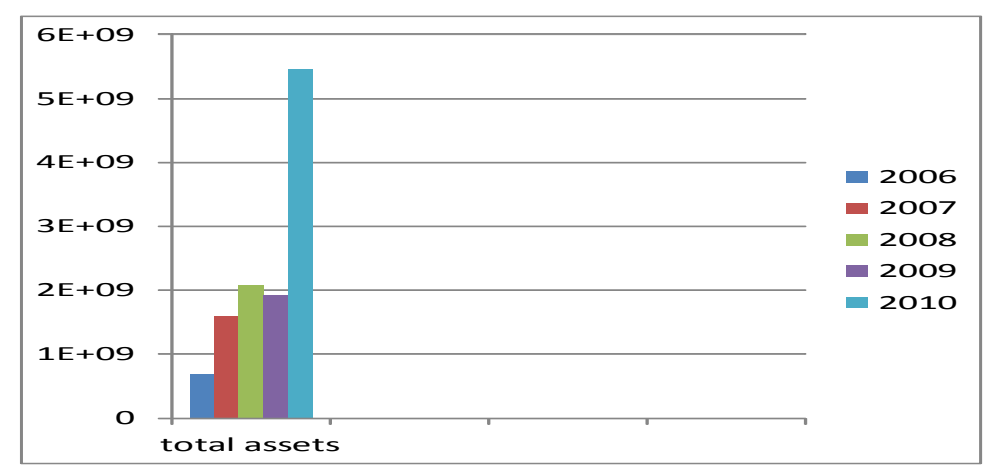

Figure 11 Data on the Development of Total Assets years 2006-2010

This phenomenon could have happened because of the extraordinary stimulation from the government to boost the establishment and growth of CMFI in the initial period initiated. In this case the government, especially the Cooperative and MSME Service, has shown good performance in its efforts to 
empower CMFIs in order to improve the economic welfare of poor women in Jember district. This result is in accordance as what was stated by Wiyono (2005) that CMFIs are one of the pillars of the Indonesian economy.

\section{E. Conclusions and Recommendations}

\section{Conclusion}

From the results of the study and analysis, it was concluded that financial performance proxied by ROA shows a different trend from total assets and government subsidies. ROA tends to decline even though there are some who showed good performance. This is contrary to the development of CMFIs' total assets, which tend to increase throughout Jember district while government subsidies are still received in a relatively similar amount from year to year. This phenomenon shows that the performance of CMFIs has not been optimal and there is still dependence on government subsidies, which shows that they still depend also on the existence of facilitators provided by the Cooperative and MSME Offices. However, some CMFIs have shown good performance and they have successfully developed this institution as the spearhead in poor women empowerment in Jember.

\section{Suggestion}

This research has a lot of limitations so that it is recommended for further research to extend the research period in order to study subtler trend movements accurately and further study is needed to reveal the phenomenon behind the results of this study. Researches also advised the Cooperatives and UMKM Offices to be more intense in providing assistance and encouragement towards the independence of POKMAS and the CMFI management so that their performance will be better in the future.

\section{F. References}

Addae-Korankye, A. 2012. Microfinance: a tool for poverty reduction in developing countries, Journal of Business and Retail Management Research, $7(1), 138-149$. 
Asmawati. 2015. Impact of Islamic microfinance on improving the income and poverty reduction on microenterprises in Province Aceh: Case study in Baitul Qiradh Aceh, Kontekstualita, 30(2), 154-165.

Deloach, S.B., \& Lamnna, E. 2011. Measuring the impact of microfinance on child health outcomes in Indonesia, World Development, 39(10), 18081819.

Oguejiofor, A., \& Unachukwu, U. 2014. Achieving poverty reduction through microfinance: evidences from the Philippines, Developing Country Studies, 4(8), 121-138.

Parianom, R. 2013. Pemberdayaan Lembaga Keuangan Mikro Untuk Pembangunan Ekonomi Pedesaan. Jurnal Bijak, 10 (2): 1-17.

Robinson, M.S. 2002. The Microfinance Revolution, Sustainable Finance for the Poor, Vol. 1. Washington: The World Bank, D.C. New York Open Society Sabiti, M.B., \& Effendi, J. 2017. Islamic microfinance and its impact on poverty reduction in Bogor, Signifikan: Jurnal Ilmu Ekonomi, 6(1), 87-102.

Samer, S., Majid, I., Rizal, S., Muhamad, M.R., Halim, S., \& Rashid, N. 2015. The impact of microfinance on poverty reduction: Empirical evidence from Malaysian perspective, Procedia - Social and Behavioral Sciences, 195, 721-728.

Sukarno, H. \& Damayanti, D. 2012. Bank Gakin: Telaah Kinerja Lembaga Keuangan Mikro di Jember. Prosiding Seminar dan Konferensi Nasional Manajemen Bisnis. pp. 73-79

Supeni, R.I. \& Sari, M.I. 2013. Pengembangan Manajemen Usaha Kecil Sederhana sebagai Model Pemberdayaan Ekonomi Perempuan Miskin. Prosiding Seminar Nasional Perempuan dalam Penelitian, Jember. pp. 129-162.

Uchida, H., Udell, G.F., \& Watanabe, W. 2008. Bank size and lending relationships in Japan. Journal of the Japanese and international Economies, 22(2): 242-267.

Usman, A. 2015. Analysis the impact of microfinance on poverty reduction, Journal of Poverty, Investment and Development, 13, 104-116.

Wijaya, K. (2005). Kredit Mikro Bukan Hibah. Harian Kompas, Selasa, 1.

Wijono, W.W. (2005). Pemberdayaan LKM Sebagai salah satu Pilar Sistem Keuangan Nasional: Upaya Konkrit memutus Mata rantai Kemiskinan. Jurnal Kajian Ekonomi dan Keuangan, Special Edition, November 2005. 